\title{
Optimal Taxation of Risky Human Capital
}

\author{
BAS JACOBS \\ DIRK SCHINDLER \\ HONGYAN YANG
}

CESIFO WORKING PAPER NO. 2529

CATEGORY 1: PUBLIC FINANCE

JANUARY 2009
An electronic version of the paper may be downloaded
- from the SSRN website: $\quad$ www.SSRN.com
- from the RePEc website: $\quad$ www.RePEc.org
- from the CESifo website: www.CESifo-group.org/wp




\title{
Optimal Taxation of Risky Human Capital
}

\begin{abstract}
In a model with ex-ante homogenous households, earnings risk and a general earnings function, we derive the optimal linear labor tax rate and optimal linear education subsidies. The optimal income tax trades off social insurance against incentives to work and to invest in human capital. Education subsidies are not used for social insurance, but are only targeted at off-setting the distortions of the labor tax and internalizing a fiscal externality. Both optimal education subsidies and tax rates increase if labor and education are more complementary, since education subsidies indirectly lower labor tax distortions by stimulating labor supply. Optimal education subsidies (taxes) also correct non-tax distortions arising from missing insurance markets. Education subsidies internalize a positive (negative) fiscal externality if there is underinvestment (overinvestment) in education due to risk. Education policy unambiguously allows for more social insurance if education is a risky activity. However, if education hedges against labor market risk, optimal tax rates could be lower than without education subsidies.
\end{abstract}

JEL Code: H21, I2, J2.

Keywords: labor taxation, human capital investment, education subsidies, idiosyncratic risk, risk properties of human capital.

\author{
Bas Jacobs \\ School of Economics \\ Erasmus University Rotterdam \\ PO Box 1738 \\ The Netherlands - 3000 DR Rotterdam \\ bjacobs@few.eur.nl \\ Dirk Schindler \\ University of Konstanz \\ Fach D133 \\ Germany - 78457 Konstanz \\ dirk.schindler@uni-konstanz.de \\ Hongyan Yang \\ University of Konstanz \\ Fach D133 \\ Germany - 78457 Konstanz \\ hongyan.yang@uni-konstanz.de
}

January 11, 2009

This paper has benefited from discussion with Joana Pereira and comments by participants at conferences and seminars in Konstanz, Maastricht, Graz, Trondheim, Bergen, Rotterdam, Gießen and Marburg. Bas Jacobs is grateful to the Dutch Organization for Sciences for generous financial support (Vidi Grant No. 452-07-013, 'Skill Formation in Distorted Labor Markets'). 


\section{Introduction}

Insuring human capital risks is one of the key roles of modern welfare states. Individuals face large labor market risks during their working lives. They may become unemployed, sick, disabled or they may experience loss of skill due to old age, health problems, technological changes, and globalization. Indeed, virtually all social benefits (for example welfare, unemployment, sickness, disability, health, or old age benefits) provide insurance against the loss of skill. Moreover, if individuals fail to acquire sufficient skills when young, they are liable to become dependent on social insurance benefits later on in life. Therefore, human capital policies could be necessary to avoid dependency on the welfare state. Despite the obvious policy relevance, it is rather surprising that only a limited number of papers have addressed the question of how social insurance should be organized when human capital is subject to non-insurable risks. Moreover, it is not clear whether education policy should be employed as a complementary policy to social insurance.

Some earlier papers have analyzed the implications of human capital risks for the design of optimal insurance and/or education policy. See, for example, Eaton and Rosen (1980a, 1980b), Hamilton (1987), and Anderberg and Andersson (2003). Grochulski and Piskorski (2006), da Costa and Maestri (2007), and Anderberg (2008) follow the so called new dynamic public finance approach to analyze optimal tax and education policies when human capital is subject to risk. The findings in this literature differ, depending on: the available policy instruments; whether linear or non-linear policy instruments are chosen; and whether education increases or decreases earnings risk. None of these papers explicitly derives answers to the following three questions.

Firstly, is the optimal amount of social insurance higher or lower when education increases or reduces earnings risk? Anderberg and Andersson (2003, p. 1523) argue that: "If human capital reduces earnings risk, encouraging education would seem to mitigate the insurance / redistribution problem." Hence, if education hedges against labor market risk (increases labor market risk), the government needs to rely less (more) on social insurance. However, this argument is not formally proven.

Secondly, should education policy correct under-or overinvestment in human capital, or not? Human capital investment is typically inefficient, because risk-averse individuals try to reduce their exposure to income risk in the presence of missing insurance markets. Da Costa and Maestri (2007, p. 696) suggest that education policy is optimal if education is a risk-increasing activity: "Optimal policies derived under these assumptions will then prescribe ... educational subsidies to ameliorate the problem of under-investment in human capital." Anderberg and Andersson (2003, p. 1523) argue in contrast that education policy is also needed, but now when education hedges against income risk: "The insight is thus that if education moderates wage uncertainty, a second-best policy should, rather unambiguously, encourage the formation of human capital (relative to the first-best), 
while if education exacerbates wage uncertainty the overall conclusion is ambiguous."

Thirdly, does the availability of education policy optimally increase the amount of social insurance or not? Again, one would expect this to be true. For example, Bovenberg and Jacobs (2005) demonstrate in deterministic settings that optimal education policy typically lowers the cost of redistribution and thus raises optimal tax rates.

We demonstrate that the answers to these three questions are not trivial and can be completely counterintuitive. Indeed, we show that all the suggested answers to the questions raised above are either partially or completely incorrect. The aim of the present paper is thus to clarify a number of important issues in this small literature and to provide a number of new insights. We do so by developing a canonical model, which integrates the previously studied approaches in order to characterize optimal linear tax and education policies in risky economies.

We study a one-shot model of human capital investment and labor supply. Ex-ante homogenous households differ ex-post due to the realization of idiosyncratic risk in their ex-post income. Markets to insure earnings or human capital risks are missing. Therefore, social insurance is welfare enhancing as we assume that there is no aggregate risk. Social insurance takes the form of a linear income tax. ${ }^{1}$ Full insurance is impossible due to the endogeneity of labor supply, which causes a moral hazard problem. We extend the previous literature by employing a completely general earnings function that depends on human capital investment, labor supply and a random variable reflecting the uncertain state of nature. This general earnings function allows both for the possibility that education is a risky activity that increases exposure to labor market risk and the possibility that education reduces exposure, i.e., hedges, against labor market risk. Our model is sufficiently general to fully explore the nature of optimal tax and education policies while remaining analytically tractable. In doing so, our paper contributes in five major ways to the existing literature.

Firstly, we provide the answer to the first question. We show that if educational investment increases exposure to non-insurable income risks, the risk-premium acts as a (pre-existing) implicit tax on human capital. Missing insurance markets therefore result in non-tax distortions, which generate fiscal externalities that need to be taken into account when designing tax and education policies. Income taxes exacerbate (mitigate) underinvestment (overinvestment) in human capital when insurance markets are missing, so that income taxes should optimally be lower (higher) as a result. Therefore, if education hedges against (increases) labor market risk, it is incorrect to argue that optimal income taxes should be lower (higher) because individuals self-insure by overinvesting (underinvesting).

Secondly, we answer the second question by demonstrating that education subsidies

\footnotetext{
${ }^{1}$ We restrict income taxes and education subsidies to be linear. Anderberg (2008) explores similar questions with non-linear instruments.
} 
are not used for insurance. Indeed, when there is no social insurance, governments cannot improve upon the laissez faire outcome by subsidizing education as this will upset the optimal private response to market risk. As long as insurance markets are missing and social insurance is unavailable, it is therefore incorrect to argue that governments should correct under- or overinvestment in human capital with education subsidies.

Thirdly, we show that education subsidies are optimally employed in an income tax cum education subsidy policy. Indeed, subsidies on education are optimal only in combination with social insurance in order to mitigate the tax and non-tax distortions associated with social insurance. The first role of education subsidies is to reduce the tax distortions on labor supply if education is complementary to labor. Education subsidies then boost labor supply, and thereby indirectly off-set the labor tax distortion on work effort (see also Jacobs and Bovenberg, 2008). ${ }^{2}$ The second role of education subsidies is to internalize the fiscal externality caused by under- or overinvestment in education. Da Costa and Maestri (2007) are indeed correct to argue that education should be subsidized if it is a risky activity, but only to the extent that subsidies are needed to internalize the fiscal externality, and not to directly tackle over- or underinvestment (see the previous point). Similarly, when education reduces labor market risk, lower education subsidies (or even taxes) should optimally be used so as to off-set the non-tax distortion resulting in overinvestment. If human capital hedges against income risks, and if individuals make their own investment choices rather than the government making these choices, it is erroneous to conclude that private investment in human capital should be encouraged with education subsidies for insurance reasons.

Fourthly, we answer the third question. When both tax and education policies are optimized, we demonstrate that the design of social insurance becomes independent from the question whether education is a risky investment or not. Therefore, ambiguities arise as to whether more or less social insurance is provided compared to the optimal tax policy without education subsidies. This crucially depends on the risk properties of human capital and the complementarity of education and work. Consequently, optimal education policy does not automatically allow for more social insurance.

Fifthly, our paper is the complement to Anderberg (2008) who analyzes non-linear tax and education policies in comparable settings. We bolster his findings by showing that the risk properties of human capital are critical in shaping human capital policies also under much weaker informational assumptions. In particular, only aggregate labor incomes and educational investments need to be verifiable to the government for linear policy instruments to be employed. Moreover, our findings suggest that great care should

\footnotetext{
${ }^{2}$ This corresponds to the 'revenue effect' in Anderberg and Andersson (2003). This finding contrasts, however, with Bovenberg and Jacobs (2005). They show that education should not be subsidized (on a net basis) because education subsidies also generate inequality if more able individuals learn more ('ability bias'). This effect is absent here, since all individuals are ex ante identical and invest the same amount in education.
} 
be taken when drawing inferences from the wedges that are now commonly analyzed in the new dynamic public finance literature. We show that a tax wedge on education does not prove that education is optimally taxed at the optimal second-best allocation, which is decentralized through income taxes and education subsidies.

The remainder of this paper is structured as follows. Section 2 provides a survey of the literature. Then the model is introduced in section 3. Section 4 discusses optimal tax and education policies. The paper ends with conclusions and discussion in section 5 .

\section{Earlier Literature}

Levhari and Weiss (1974) are the first to examine the effect of idiosyncratic risks on human capital formation in the absence of well-functioning markets to insure these risks. Assuming an exogenous labor supply decision $(\bar{l})$, they postulate a general earnings function $\Phi(\theta, e, \bar{l}) \equiv \phi(\theta, e)$, which denotes gross labor earnings and depends on a risky component $\theta$ and the level of human capital investment (education) e. Typically, $\theta$ is seen as a random variable with some ex ante known distribution. Levhari and Weiss (1974, p. 951) distinguish between 'input' and 'output' risk in human capital investment. Input risk is the risk of being successful in acquiring human capital due to, e.g., imperfect knowledge about (learning) ability or about the quality of education. Output risk denotes the risk in the returns to human capital arising from uncertainty about labor market conditions, e.g., employment and wage risk.

Levhari and Weiss (1974) suggest that for input risk, it is quite 'natural' to assume that $\Phi_{\theta e}>0$. Hence, income risk increases in the level of educational investment. Therefore, risk averse individuals will reduce their exposure to the risk of failing by underinvesting in human capital. Indeed, many papers suggest that human capital is risky. ${ }^{3}$ However, $\Phi_{\theta e}>0$ may not be the most appropriate assumption to capture output risk. Typically, better educated individuals experience less unemployment, sickness and wage risk (among other things). ${ }^{4}$ Therefore, if education reduces the exposure to labor market risk, the cross derivative of the earnings function is negative, i.e., $\Phi_{\theta e}<0$. Then, risk averse individuals try to reduce their exposure against unfavorable labor market outcomes by overinvesting in education, since education hedges against adverse labor market outcomes.

Self-insurance by over- or underinvesting is socially inefficient, although it is rational at the individual level. Idiosyncratic income risks can be pooled, since the law of large numbers ensures that there is no aggregate uncertainty. In principle, private insurance

\footnotetext{
${ }^{3}$ Palacios-Huerta $(2004,2006)$ shows that human capital is risky on average and even speaks of a human capital premium puzzle, since the return to education is so high that it can only be explained by implausibly huge coefficients of risk-aversion. Hartog (2005) reviews a whole literature that empirically establishes risk-compensation in wages.

${ }^{4}$ See also Gould et al. (2000) and Belzil and Hansen (2004). Using an empirical approach, PalaciosHuerta $(2004,2006)$ finds that the human capital premium is lowered as workers become better educated.
} 
should therefore be possible at very low or even no costs. Nevertheless, in the case of human capital, private insurance markets tend to suffer from market failure and private insurance is not (or only to a very limited extent) available due to moral hazard, adverse selection, and various legal limitations in trading claims on human capital. See Sinn (1996) for an elaborate discussion. Because private markets are incomplete, social welfare could in principle be increased by public intervention. Although all social insurance policies suffer from moral hazard problems, ${ }^{5}$ the government may overcome adverse selection and legal problems by providing mandatory social insurance against human capital risk. How should optimal social insurance in that case be designed?

Eaton and Rosen (1980a) study the optimal design of social insurance at exogenous levels of human capital $(\bar{e})$. The earnings function is designated by $\Phi(\theta, \bar{e}, l) \equiv \theta l$, so that the risk factor $\theta$ enters in a multiplicative fashion. A proportional income tax is shown to be preferable to pure lump-sum taxation. A proportional tax rate, while returning the tax revenue as a deterministic lump-sum transfer, redistributes labor incomes across states of nature and therefore provides insurance. However, redistribution also distorts labor supply. Starting from a situation without income taxation, the welfare gain of correcting missing insurance markets is first-order, while the labor supply distortion is only second-order. Therefore, the income tax is optimally positive. ${ }^{6}$

The formal analysis of social insurance with endogenous human capital investment began with the seminal paper by Eaton and Rosen (1980b). They use a multiplicative modeling of risk, so that the earnings function looks like: $\Phi(\theta, e, l) \equiv \theta \phi(e) l$, where $\Phi_{\theta e}>0$, and education $e$ is risk-increasing. Consequently, private educational investment is below the socially desirable level. The introduction of a proportional income tax is welfare-enhancing. The intuition is again that the income tax redistributes income from favorable to unfavorable states of nature. By replacing missing insurance markets, the linear income tax boosts risky human capital investment. ${ }^{7}$

Hamilton (1987) basically adopts the model of Eaton and Rosen (1980b), but in addition analyzes taxes on savings. Hamilton points out that, even though taxation provides some (social) insurance, there is still underinvestment in human capital, which is socially inefficient. It would, therefore, be preferable to give the government full control over human capital investment to avoid this underinvestment. Direct control of human capital is, however, unrealistic in his view. Hamilton proposes an interest tax as indirect subsidy on educational investment. Interest taxation decreases the opportunity costs of human capital accumulation. A positive tax rate on interest, accompanying positive proportional wage taxation, is shown to be optimal under the (very) strong assumptions

\footnotetext{
${ }^{5}$ See for example Wigger and von Weizsäcker (2001) for a detailed analysis.

${ }^{6}$ Varian (1980) derives similar results in a model with a risky return to capital investment and generalizes the result to non-linear income taxation.

${ }^{7}$ This analysis is extended to progressive labor taxation and the simultaneous use of education subsidies in Schindler and Yang (2007).
} 
of (i) inelastic labor supply and (ii) either zero equilibrium savings or constant absolute risk aversion.

Grochulski and Piskorski (2006) generalize the findings of Hamilton (1987) to nonlinear policy instruments without imposing the strong restrictions on the model, while maintaining an earnings function with multiplicative risk: $\Phi(\theta, e, l) \equiv \theta \phi(e) l$. At the same time, they do not allow for education policy, as education is assumed to be non-verifiable to the government. They show that labor supply carries a wedge (i.e., is distorted) for insurance purposes. This is the analogous to the optimality of a distortionary labor tax. Moreover, there is an intertemporal wedge in consumption choices, indicating a role for capital income taxation. Firstly, the capital tax stimulates labor supply, and indirectly reduces the labor tax distortion on labor supply (see also Diamond and Mirrlees, 1978, 1986; Golosov et al., 2003). ${ }^{8}$ Secondly, by lowering the opportunity costs, capital income taxes give incentives to invest in human capital. This is optimal because the labor tax discourages human capital investments, since costs of education are not tax-deductible. Capital income taxes are optimally positive, because introducing a saving distortion is only second-order, while removing the tax distortion on human capital is first-order. The capital tax therefore improves the composition of overall saving while hurting the overall level of both human and financial savings. See also Jacobs and Bovenberg (2005) who obtain the same result even in the absence of risk.

Anderberg and Andersson (2003) are the first to simultaneously optimize linear tax and education policies. They use a stripped-down version of the Eaton and Rosen (1980b) model, while allowing for a more general earnings function, as in Levhari and Weiss (1974). In particular, gross labor earnings depend on a stochastic factor $\theta$, educational investment $e$, and labor $l$ : $\Phi(\theta, e, l) \equiv \phi(\theta, e) l$. Both risk-increasing $\left(\Phi_{\theta e}>0\right)$ and riskdecreasing $\left(\Phi_{\theta e}<0\right)$ cases are considered. Anderberg and Andersson (2003) assume that the government fully and directly controls educational investment. Also these authors obtain a trade-off between social insurance and tax-induced distortions in labor supply. In addition, they find that the use of education policy generates a 'revenue creation effect' because labor supply and education are complementary activities, so that education policy can mitigate the tax distortions on labor supply. Moreover, education policy entails an 'insurance effect' depending on the risk properties of human capital. They derive conditions under which each effect calls for over- or underprovision of education compared to the first-best outcome without missing insurance markets. Although the two effects may pull in opposite directions, their main message is that education should be overprovided if it is risk-decreasing and it should be underprovided if it is risk-increasing.

\footnotetext{
${ }^{8}$ Cremer and Gavhari (1995a, 1995b) also demonstrate that the optimal (linear) commodity tax is non-uniform under both linear and non-linear income taxation, when one of the commodities is consumed before the realization of risk and the other thereafter. If we interpret these commodities as consumption today and consumption tomorrow, the result is immediate. Hence, intertemporal wedges or capital income taxes are optimal.
} 
Da Costa and Maestri (2007) and Anderberg (2008) also build on the Eaton-RosenHamilton model, but now assume that human capital investments can be verified by the government so that it can employ non-linear education policies, besides non-linear policy instruments on labor income and capital income. These authors confirm earlier findings by Golosov et al. (2003) that there is optimally an intertemporal wedge on consumption (i.e., a role for capital income taxation). Similarly, labor supply carries a wedge for social insurance purposes. Da Costa and Maestri (2007) argue that education policy should ensure social efficiency in human capital investment. Anderberg (2008) concludes this result to be erroneous. Aggregate human capital investment should be optimally distorted in a way that depends on the shape of the earnings function similar to Anderberg and Andersson (2003).

Taken together, all these papers show that social insurance is desirable, but that a moral hazard problem in labor supply prevents full insurance. Moreover, in principle there is a welfare enhancing role for education policy. Levhari and Weiss (1974), Anderberg and Andersson (2003) and Anderberg (2008) show that the nature of human capital risk is critical for both individual behavior and tax and education policy. But what does the optimal income tax look like? An explicit analysis of the role of education subsidies to implement the optimal second-best allocation as a market outcome is still missing. How should education policies be designed if the government implements the second-best with linear education subsidies? And, finally, how do the optimal linear income taxes and linear education subsidies depend on the risk properties of human capital? The rest of this paper is devoted to answer these questions.

\section{The Model}

\subsection{Preferences and Technologies}

Following Levhari and Weiss (1974), mainly two-period models are analyzed in the literature. There is a continuum of ex-ante identical individuals, who have to decide on their educational investment, labor supply and consumption. In the first period, individuals have a unit time endowment, which is spent on investment in education $(e)$, and work $(1-e)$. $w_{o}$ is the wage per year worked. Consequently, individuals forego labor earnings while learning. ${ }^{9}$ Generally, there is no labor-leisure decision in the first period, only in the second. Apart from investing in education, individuals may also save (or borrow). Savings are denoted by $a$. Capital markets for borrowing and lending are perfect.

\footnotetext{
${ }^{9}$ Without any loss of generality we could also allow for direct costs of education, besides opportunity costs, as long as all educational investments are verifiable and can be subsidized (cf. Bovenberg and Jacobs, 2003, 2005).
} 
Consequently, we can write the first-period budget constraint as

$$
c_{o}=\omega+w_{o}(1-e)-a,
$$

where $c_{o}$ is consumption in the first period, and $\omega$ is an exogenous initial income endowment.

In the second period, individuals supply labor and consume their savings plus labor incomes. Gross labor income is represented by a general earnings function, which depends on labor $l$ and education $e$ :

$$
\Phi(\theta, l, e), \quad \Phi_{e}, \Phi_{l}>0, \quad \Phi_{e e}<0, \quad \Phi_{l l} \leq 0 .
$$

$\theta$ is an idiosyncratic shock drawn from a probability distribution $f(\theta)$. Therefore, both income and the returns to education are risky. We assume that, for any given value of $\theta$, the marginal returns to education are positive and decreasing. Similarly, the marginal returns to labor effort are positive and non-increasing. Furthermore, the random variable $\theta$ is assumed to have a positive effect on income: $\Phi_{\theta}>0$. In the remainder of the analysis, we focus on the two cases identified in the literature: (i) educational investment itself causes and amplifies income risks $\left(\Phi_{\theta e}>0\right)$, and (ii) educational investment hedges against income risks $\left(\Phi_{\theta e}<0\right)$. The second-period budget constraint thus reads as

$$
c=\Phi(\theta, l, e)+(1+r) a,
$$

where $c$ is consumption in the second period, and $r$ is the constant real interest rate. We abstract from taxes on saving and refer to Hamilton (1987) for that case.

Households derive utility from consumption and disutility from labor. They maximize a von Neumann-Morgenstern expected utility function

$$
\mathcal{E}\left[U\left(c_{o}, c, l\right)\right], \quad U_{c_{o}}, U_{c},-U_{l}>0, \quad U_{c_{o} c_{o}}, U_{c c},-U_{l l} \leq 0
$$

where $\mathcal{E}$ denotes the expectation operator, i.e., $\mathcal{E}[X] \equiv \int_{\Theta} X d f(\theta)$ where $\Theta$ is the set of values for $\theta$. $U$ is assumed to be strictly concave, three times differentiable, and it satisfies the Inada conditions.

We reduce this basic two-period model to its canonical form by making the following innocent assumptions. Firstly, we treat first-period consumption $c_{o}$ as exogenously fixed as in Eaton and Rosen (1980b). Moreover, we set it equal to zero $\left(c_{o}=0\right)$, for the reason that the intertemporal allocation of consumption is only of secondary interest if capital markets are perfect. Secondly, we normalize the interest rate to zero, $r=0$, for the same reason. Thirdly, we normalize the first-period wage rate to one $\left(w_{o}=1\right)$, which is harmless. Fourthly, we assume that the income endowment is equal to $\omega=-w_{0}=-1$. 
Consequently, we can suppress the time endowment in the household budget constraint. This assumption is innocent since the taxes on the time spent working in the first period will only cause income effects and will not generate (policy relevant) substitution effects (see also Bovenberg and Jacobs, 2003).

In addition, we assume that social insurance takes place through a linear tax system with a positive marginal tax rate $t$ and a lump-sum transfer $T$, which can be seen as a negative income tax or a basic income. Furthermore, we introduce a flat rate subsidy $s$ on the opportunity costs of education (forgone earnings). Moreover, all educational investments are fully tax deductible. Hence, under our assumptions, net life-time income of the representative household is given by

$$
c=(1-t)[\Phi(\theta, l, e)-(1-s) e]+T
$$

We further assume that utility is additively separable in consumption and labor supply, and we suppress first-period consumption in the utility function:

$$
U \equiv \mathcal{E}[u(c)-v(l)], \quad u^{\prime}>0, \quad u^{\prime \prime}<0, \quad v^{\prime}>0, \quad v^{\prime \prime}>0
$$

The sub-utility function of consumption is increasing and concave, whereas the disutility function of labor supply is increasing and convex. Furthermore, we impose the Inadaconditions on both utility functions to avoid corner solutions.

The timing structure of the model is as follows. The government sets the proportional tax rate $t$, the subsidy rate $s$ and the lump-sum transfer $T$ before the choices of households and the revelation of the risk $\theta$. Moreover, educational investment $e$ and labor supply $l$ are simultaneously chosen before risk realizes. ${ }^{10}$ Labor supply can therefore be used as insurance device in order to reduce exposure to income risks - analogously to education. After that, (income) risk realizes, incomes are earned and consumption takes place. Consequently, only consumption is stochastic, while working time and education are deterministic.

\subsection{Households}

The household's unconstrained maximization problem can be obtained upon substitution of the household budget constraint in the utility function:

$$
\max _{\{e, l\}} U(e, l) \equiv \mathcal{E}[u((1-t)[\Phi(\theta, l, e)-(1-s) e]+T)]-v(l),
$$

\footnotetext{
${ }^{10}$ It can be shown that a timing sequence in which labor supply is chosen after uncertainty has been resolved does not change any of the results qualitatively, cf. Cremer and Gavhari (1995a), and Anderberg and Andersson (2003).
} 
The first-order conditions for this maximization problem are given by

$$
\begin{aligned}
\mathcal{E}\left[u^{\prime}(.)\left(\Phi_{e}(.)-(1-s)\right)\right] & =0, \\
(1-t) \mathcal{E}\left[u^{\prime}(.) \Phi_{l}(.)\right]-v^{\prime}(l) & =0 .
\end{aligned}
$$

These equations can be rewritten by employing the risk premia in education and labor supply:

$$
\begin{aligned}
\pi_{e} & \equiv-\frac{\operatorname{cov}\left[u^{\prime}(.), \Phi_{e}(.)\right]}{\mathcal{E}\left[u^{\prime}(.)\right] \mathcal{E}\left[\Phi_{e}(.)\right]}, \\
\pi_{l} & \equiv-\frac{\operatorname{cov}\left[u^{\prime}(.), \Phi_{l}(.)\right]}{\mathcal{E}\left[u^{\prime}(.)\right] \mathcal{E}\left[\Phi_{l}(.)\right]}
\end{aligned}
$$

$\pi_{e}$ is the negative of the normalized covariance between marginal utility of consumption and marginal return of human capital. A positive risk premium implies that education increases income risk, since $\pi_{e}>0$ corresponds to $\Phi_{\theta e}>0$. A negative risk premium $\pi_{e}<0$, instead, mirrors a risk-reducing effect of education, due to $\Phi_{\theta e}<0$. Similarly, $\pi_{l}$ is the negative of the normalized covariance between marginal utility of consumption and marginal return to labor, representing the risk premium in labor supply. Its interpretation is analogous to the risk premium in educational investment. Note that if individuals would be risk-neutral, both risk premia would be zero. Similarly, risk premia are zero if the marginal returns to education or labor are not state-dependent, i.e., when there is no risk. Both risk premia are also zero when the risk-factor $\theta$ enters the earnings function in an additively separable fashion $\left(\Phi_{\theta e}=\Phi_{\theta l}=0\right)$, since education and labor supply do not affect income risk in that case.

Using the definition of $\pi_{e}$, the first-order condition (8) can be written as

$$
\left(1-\pi_{e}\right) \mathcal{E}\left[\Phi_{e}(\theta, l, e)\right]=1-s
$$

The risk-adjusted expected marginal return to education is equal to the marginal cost of education. Note that the tax system does not directly affect investment in education, since all costs of education are tax deductible. However, taxation generally affects investment in education indirectly via labor supply. More labor supply raises the returns to human capital investments as long as $\Phi_{e l}>0$. This is the case for all earnings functions discussed in the literature (cf. Jacobs and Bovenberg, 2008). Education subsidies naturally boost educational investments, since they reduce marginal cost.

If income is risky, the expected marginal return of education can be either higher or lower than marginal costs, depending on the sign of the risk premium $\pi_{e}$. If education increases exposure to labor market risk, $\pi_{e}>0$, individuals command a positive riskpremium on their educational investment. Hence, from a social point of view, risk-averse individuals invest too little in education. Missing insurance markets for human capital 
related income risk thus create an implicit tax on human capital investment. If income risk decreases with education, individuals command a negative risk-premium on their educational investment, $\pi_{e}<0$. In that case, risk-averse individuals invest too much in education in order to reduce their exposure to labor market risk. If human capital investments hedge against labor market risk, missing insurance markets create an implicit subsidy on human capital investments. If there is no income risk, condition (12) reduces to $\Phi_{e}()=.1-s$, which is the optimality condition for investment in human capital under certainty.

The first-order condition for labor supply (9) can be rewritten using $\pi_{l}$ :

$$
\frac{v^{\prime}(l)}{\mathcal{E}\left[u^{\prime}(.)\right]}=(1-t)\left(1-\pi_{l}\right) \mathcal{E}\left[\Phi_{l}(\theta, l, e)\right]
$$

The marginal rate of substitution between consumption and labor must be equal to the risk adjusted net wage. A higher tax rate reduces the incentives to supply labor. Note that if education raises the wage rate, incentives to supply labor are stronger when individuals are better educated. Thus, education and labor are complementary as long as $\Phi_{e l}>0$. If an increase in labor supply increases risk, $\pi_{l}>0$, individuals supply less labor than is socially efficient. If labor supply decreases the exposure to risk $\left(\pi_{l}<0\right)$, the risk premium turns negative, leading to socially inefficient precautionary labor supply. Again, the risk premium acts as an implicit tax (subsidy) on labor if labor supply increases (reduces) exposure to labor market risk, i.e., if $\pi_{l}>0\left(\pi_{l}<0\right)$.

In general, the second-order conditions for individual optimization are not automatically satisfied due to the interaction between learning and working. This generates nonlinear budget sets in which interior solutions are not guaranteed. Define $\rho \equiv-u^{\prime \prime}(.) / u^{\prime}($. as the Arrow-Pratt coefficient of absolute risk aversion and $\tilde{\Phi}_{e}(.) \equiv \Phi_{e}()-.(1-s)$ as the net marginal return to education. Then, we find that the second-order condition for expected utility maximization is given by (see Appendix A.1)

$$
\begin{aligned}
\mathcal{E}\left[u^{\prime}\left(\Phi_{e l}-(1-t) \rho \Phi_{l} \tilde{\Phi}_{e}\right)\right]^{2} & <\mathcal{E}\left[u^{\prime}\left(\Phi_{e e}-(1-t) \rho \tilde{\Phi}_{e}^{2}\right)\right] \\
& \times\left[\mathcal{E}\left[u^{\prime}\left(\Phi_{l l}-(1-t) \rho \Phi_{l}^{2}\right)\right]-\frac{v^{\prime \prime}}{(1-t)}\right]
\end{aligned}
$$

The right-hand side is generally positive, since both bracketed terms are negative: $\Phi_{e e}()<$. $0, \Phi_{l l}()<$.0 and $\tilde{\Phi}_{e}^{2}()>0,. \Phi_{l}^{2}()>0,. v^{\prime \prime}()>$.0 . If the right-hand side is positive, the left-hand side should be sufficiently small. That is the case if the complementarity between education and labor is weak (low $\Phi_{e l}$ ) and absolute risk-aversion $\rho$ is sufficiently large. This is intuitive as a stronger complementarity raises the strength of the feedback between learning and working. Weaker risk-aversion also generates a stronger feedback, since individuals who tolerate more risk will respond more elastically to changes in incen- 
tives. In the remainder we assume that the second-order conditions are always satisfied.

\subsection{Government}

We assume a benevolent government with full commitment, which maximizes social welfare by optimally choosing linear tax and education policies. The informational assumptions for employing linear instruments are that only aggregate incomes and education choices need to be verifiable to the government. We abstract from (exogenous) government spending without loss of generality.

The government budget constraint is given by

$$
\mathcal{E}[t(\Phi(.)-(1-s) e)-T-s e]=0 .
$$

All tax revenues are used to finance the lump-sum transfers and education subsidies. Since income risk is idiosyncratic, tax revenue is deterministic according to the law of large numbers and tax revenue equals its expected value. We abstract from any systematic risk. ${ }^{11}$

Social welfare is (ex ante) expected indirect utility $V($.$) of the representative house-$ hold:

$$
V(T, t, s) \equiv \mathcal{E}[u((1-t)[\Phi(\theta, \hat{l}, \hat{e})-(1-s) \hat{e}]+T)]-v(\hat{l}),
$$

where hats denote the optimized values for $l$ and $e$. For later reference, we apply Roy's lemma to find the derivatives of the indirect utility function: $\frac{\partial V(.)}{\partial T}=\mathcal{E}\left[u^{\prime}().\right], \frac{\partial V(.)}{\partial t}=$ $-\mathcal{E}\left[u^{\prime}().(\Phi()-.(1-s) e)\right]$, and $\frac{\partial V(.)}{\partial s}=\mathcal{E}\left[u^{\prime}().\right](1-t) e$.

\section{Optimal Tax and Education Policies}

The Lagrangian for maximization of social welfare is given by

$$
\max _{\{T, t, s\}} \mathcal{L} \equiv \mathcal{E}[V(T, t, s)+\eta(t(\Phi(\theta, l, e)-(1-s) e)-s e-T)]
$$

where $\eta$ denotes the Lagrange multiplier of the government budget constraint (15).

In order to characterize the optimal solutions for the optimal tax and subsidy rates, we introduce the following tax wedges on labor and education:

$$
\begin{aligned}
\Delta_{l} & \equiv t \Phi_{l}(.) \\
\Delta_{e} & \equiv t\left(\Phi_{e}(.)-(1-s)\right)-s .
\end{aligned}
$$

\footnotetext{
${ }^{11}$ Adding systematic (aggregate) income risks would make the government budget risky. This should not affect our main findings on insuring the idiosyncratic part of risk, but may require an additional insurance device in the form of public consumption. Part of the systematic risk can then be diversified by smoothing aggregate shocks over private and public consumption, see Kaplow (1994).
} 
$\Delta_{l}\left(\Delta_{e}\right)$ measures the increase in tax revenue (measured in monetary units) if labor supply (education) is raised with one unit.

The first-order conditions for this maximization problem are given by:

$$
\begin{aligned}
& \frac{\partial \mathcal{L}}{\partial T}=\mathcal{E}\left[\frac{\partial V(.)}{\partial T}-\eta+\eta \Delta_{l} \frac{\partial l}{\partial T}+\eta \Delta_{e} \frac{\partial e}{\partial T}\right]=0 \\
& \frac{\partial \mathcal{L}}{\partial t}=\mathcal{E}\left[\frac{\partial V(.)}{\partial t}+\eta(\Phi(.)-(1-s) e)+\eta \Delta_{l} \frac{\partial l}{\partial t}+\eta \Delta_{e} \frac{\partial e}{\partial t}\right]=0 \\
& \frac{\partial \mathcal{L}}{\partial s}=\mathcal{E}\left[\frac{\partial V(.)}{\partial s}-\eta(1-t) e+\eta \Delta_{l} \frac{\partial l}{\partial s}+\eta \Delta_{e} \frac{\partial e}{\partial s}\right]=0 .
\end{aligned}
$$

In the remainder of this section, we first analyze optimal tax and education policies separately. Then, we derive the optimal structure of both tax and education policies simultaneously.

\subsection{Optimal Lump-sum Transfer}

Using Roy's lemma we obtain from (20):

$$
\mathcal{E}\left[\frac{u^{\prime}}{\eta}+\Delta_{l} \frac{\partial l}{\partial T}+\Delta_{e} \frac{\partial e}{\partial T}\right]=1 .
$$

Hence, the expected social marginal value of a unit increase in lump-sum income, including the income effects on the tax base, should be equal to its resource costs, which equal unity. This corresponds to the standard condition for the optimal lump-sum transfer in optimal income taxation models (e.g., in Atkinson and Stiglitz, 1980).

\subsection{Optimal Taxation}

This section derives the optimal level of social insurance in the absence of education policy $(\bar{s}=0)$. Analogously to Feldstein's distributional characteristic (see, e.g., Feldstein, 1972, or Atkinson and Stiglitz, 1980) and in correspondence with Anderberg and Andersson (2003), we define the 'insurance characteristic' $\xi$ as the negative of the normalized covariance between gross income $\Phi$ and the private marginal value of income $u^{\prime}$ :

$$
\xi \equiv-\frac{\operatorname{cov}\left[\Phi, u^{\prime}\right]}{\mathcal{E}[\Phi] \mathcal{E}\left[u^{\prime}\right]}
$$

The insurance characteristic $\xi$ measures the (marginal) gain in social welfare of having one euro more income insurance. A positive insurance characteristic implies that lucky individuals, having high incomes after realization of risk, have a lower marginal utility of income, and unlucky individuals, having low incomes ex post, have a high marginal utility of income. Consequently, $\operatorname{cov}\left[\Phi, u^{\prime}\right]<0$. Reducing the variance in gross earnings 
by means of redistributive income taxes thus raises social welfare. Indeed, $\xi=0$ if the government is not concerned about income insurance and all individuals have the same marginal utility of income $u^{\prime}$, or if household income $\Phi$ is deterministic, and there is no ex post inequality.

Using Roy's lemma and the risk-adjusted Slutsky equations, we can find the optimal tax rate from (21) at the optimal $T$ (see Appendix A.3):

$$
\frac{t}{1-t}=\frac{\xi}{\varepsilon_{l t}+\pi_{e} \varepsilon_{e t}}
$$

where $\varepsilon_{l t}=-\frac{\mathcal{E}\left[\Phi_{l}\right] l}{\mathcal{E}[\Phi]} \frac{\partial l^{*}}{\partial t} \frac{1-t}{l}$ and $\varepsilon_{e t}=-\frac{\mathcal{E}\left[\Phi_{e}\right] e}{\mathcal{E}[\Phi]} \frac{\partial e^{*}}{\partial t} \frac{1-t}{e}$ are the expected utility compensated elasticities of labor supply and education (see Appendix A.2). These are weighted by the expected earnings shares of labor and education in total earnings. The expression in (25) shows the trade-off between insurance and efficiency. The optimal tax on labor equates the marginal benefits of income insurance $(\xi)$ with the marginal costs of providing it. The optimal tax rate increases when the government attaches a larger social value to income insurance as measured by a higher $\xi$.

The marginal costs consist of two terms: (i) tax-induced distortions on labor supply $\frac{t}{1-t} \varepsilon_{l t}$, and (ii) a fiscal externality, $\frac{t}{1-t} \pi_{e} \varepsilon_{e t}$, stemming from the missing insurance markets. ${ }^{12}$ The optimal tax decreases if the distortions in labor supply become more severe as indicated by a higher elasticity $\varepsilon_{l t}$. Indeed, if labor supply (and educational investments) would be completely inelastic $\left(\varepsilon_{l t}=\varepsilon_{e t}=0\right)$, the optimal tax rate would be one hundred percent $(t=1)$.

The optimal tax rate is also determined by the tax elasticity of investments in education, as can be seen from the presence of the term $\pi_{e} \varepsilon_{e t}$. In particular, the income tax may exacerbate or mitigate the non-tax distortions arising from the missing insurance markets. If education increases the exposure to labor market risk, the risk premium acts as if there is a pre-existing implicit tax on educational investment $\left(\pi_{e}>0\right)$. If educational investments hedge against labor market risk, the risk premium acts as if there is a preexisting implicit subsidy on educational investment $\left(\pi_{e}<0\right)$. Provided that investment in human capital falls with a higher tax rate $\left(\varepsilon_{e t}>0\right)^{13}$, a higher income tax thus exacerbates (mitigates) underinvestment (overinvestment) in human capital if $\pi_{e}>0\left(\pi_{e}<0\right)$. The implicit tax (or subsidy) on education due to non-insurable income risks, thereby, creates a fiscal externality in the presence of positive income taxes.

This can be seen most clearly from the (expected) tax wedge on education $\mathcal{E}\left[\Delta_{e}\right]$, which

\footnotetext{
${ }^{12}$ Following Heller and Starrett (1976), we interpret the (fiscal) impact of allocative distortions resulting from a missing market as an externality. Our fiscal externality thus affects the government budget only in the case of non-zero taxes.

${ }^{13}$ Although the tax system does not affect human capital investments directly, it does so indirectly by lowering labor supply as long as labor and education are complementary in generating gross income (i.e., $\left.\Phi_{e l}>0\right)$.
} 
measures the gain in tax revenue available for redistribution if human capital investment increases by one unit. By applying the first-order equation for optimal human capital investment (12), we can rewrite the expected net tax wedge on education as

$$
\left.\mathcal{E}\left[\Delta_{e}\right]\right|_{s=0}=\frac{\pi_{e}}{1-\pi_{e}} t
$$

$\frac{\pi_{e}}{1-\pi_{e}}$ represents the risk wedge on human capital investment. If there is underinvestment $\left(\pi_{e}>0\right)$ the social marginal benefits of an additional unit invested in education are larger than its social marginal costs. Consequently, the cost of the tax deduction on the marginal costs of the investment is smaller than the tax revenue from the marginal benefits of the investment in education, i.e., $\left.\mathcal{E}\left[\Delta_{e}\right]\right|_{s=0}>0$. Income taxation will exacerbate socially undesirable underinvestment by further reducing educational investments below first-best levels (if $\varepsilon_{e t}>0$ ), which decreases tax-revenues. Consequently, optimal tax rates are set lower (ceteris paribus). In the case of overinvestment $\left(\pi_{e}<0\right)$, the opposite holds true. In particular, the public cost of the tax deduction on the marginal costs of the investment is larger than the marginal revenue generated by taxing the returns to education, i.e., $\left.\mathcal{E}\left[\Delta_{e}\right]\right|_{s=0}<0$. Social insurance thus reduces socially undesirable overinvestment in human capital (if $\varepsilon_{e t}>0$ ). Optimal tax rates are set higher as a result (ceteris paribus). If education has no effect on the exposure to risk, there is no risk-premium on human capital investment $\left(\pi_{e}=0\right)$. Thus, the implicit tax on education is zero, because all costs are deductible against the rate at which returns are taxed. Hence, the fiscal externality vanishes. In that case, the optimal tax is only determined by the labor supply elasticity. ${ }^{14}$

We find the results of Eaton and Rosen (1980b) if we assume that the earnings function exhibits multiplicative risk. The latter implies that education will always increase the exposure to risk and there will be underinvestment, i.e., $\pi_{e}>0$. However, Eaton and Rosen (1980b, pp. 712-714) do not derive an explicit expression for the optimal tax rate. We show that the optimal income tax is downward biased due to the negative fiscal externality $\left(\pi_{e}>0\right)$, which is a novel finding. If we assume that human capital investment is exogenous $\left(\varepsilon_{e t}=\pi_{e}=0\right)$, we obtain the outcome of Eaton and Rosen (1980a): $\frac{t}{1-t}=\frac{\xi}{\varepsilon_{l t}}$. This formula captures the trade-off between insurance and labor supply distortions. The next proposition summarizes our findings from this subsection.

Proposition 1. The optimal income tax trades off social insurance against the incentives to work, the incentives to invest in human capital, and the internalization of the fiscal externality stemming from missing insurance markets. If education increases exposure to labor market risk, the income tax exacerbates the distortions of missing insurance markets on human capital investment. If education reduces exposure to labor market risk,

\footnotetext{
${ }^{14}$ The tax distortions in labor supply are still typically higher than in standard models without endogenous human capital investment, as long as education and labor are complementary in earnings, see, e.g., Jacobs (2005).
} 
the income tax mitigates the distortions of missing insurance markets on human capital investment.

\subsection{Optimal Education Policy}

This section derives the optimal education policy for a given level of taxation $\bar{t}$. In doing so, we gain the intuition for the optimal structure of taxes and subsidies when both policy instruments are simultaneously optimized. By using Roy's lemma and the Slutsky equations, we can rearrange the first-order condition for education subsidies (22) to find the optimal subsidy rate at optimal $T$, for a given $\bar{t}$ (see Appendix A.4)

$$
\frac{s}{1-s}=\left(\frac{\frac{\varepsilon_{l s}}{\varepsilon_{e s}}}{1-\pi_{e}}+\frac{\pi_{e}}{1-\pi_{e}}\right) \bar{t}
$$

$\varepsilon_{l s}=\frac{\mathcal{E}\left[\Phi_{l}(.)\right] l}{\mathcal{E}[\Phi(.)]} \frac{\partial l^{*}}{\partial s} \frac{1-s}{l}$ and $\varepsilon_{e s}=\frac{\mathcal{E}\left[\Phi_{e}(.)\right] e}{\mathcal{E}[\Phi(.)]} \frac{\partial e^{*}}{\partial s} \frac{1-s}{e}$ denote the expected utility compensated elasticities of labor and education with respect to the education subsidy. These elasticities are again weighted by the expected shares of labor and education in total earnings.

The insurance characteristic is absent in the expression for optimal education subsidies. In contrast to the optimal income tax - see previous section - there is no gain in using education subsidies for insurance. Education subsidies are not used at all $(s=0)$ when the income tax is zero $(\bar{t}=0)$. In that case, the only way households can reduce their exposure to risk is to self-insure, i.e., to over- or underinvest in education. This selfinsurance is chosen optimally. Education subsidies do not yield additional welfare gains in absence of income taxation $(\bar{t}=0)$, because education subsidies are state-independent. Education subsidies therefore do not directly reduce the exposure to income risk. Consequently, in the absence of tax-provided social insurance, the government cannot improve market outcomes by subsidizing education as this policy would only upset the optimal private responses of individuals to income risk.

There is a role for education policy, however, when the government organizes social insurance through an income tax system $(\bar{t}>0)$. At an exogenously given tax rate $\bar{t}>0$, education subsidies correct the tax-distortions of the income tax. There are two reasons why education subsidies are optimally employed. First, labor taxation distorts labor supply. If $\varepsilon_{l s}>0$ education and labor supply are complementary in generating income. Thus, by subsidizing education, the government can indirectly boost labor supply and thereby reduce the tax distortions on labor supply. The higher is the tax rate $t$, the larger are the distortions on labor supply, and the larger is the need to fight these labor-tax distortions with education subsidies. Similarly, if education and labor are substitutes, $\varepsilon_{l s}<0$, education should be taxed so as to increase labor supply and to off-set the tax wedge on labor. See also Jacobs and Bovenberg (2008). In both cases the government trades off fewer tax-induced distortions on labor supply against larger subsidy-induced 
distortions in educational investment. The higher is the cross-elasticity of labor supply with respect to the education subsidy $\left(\varepsilon_{l s}\right)$, the more effective education subsidies are to fight labor-tax distortions indirectly and the higher education subsidies should be. In addition, the more education responds to subsidies (larger $\varepsilon_{e s}$ ), the larger is the social cost of undesirable overinvestment, and the lower is the optimal education subsidy.

Second, the education subsidy internalizes the fiscal externality, which is caused by the implicit tax on educational investment arising from missing insurance markets. This effect is represented by the second term, $\frac{\pi_{e}}{1-\pi_{e}} \bar{t}$, in equation (27). Note that this term equals the implicit tax wedge on education in equation $(26),\left.\mathcal{E}\left[\Delta_{e}\right]\right|_{s=0}$, where education subsidies are absent. Consequently, the education subsidy fully internalizes the fiscal externality arising from under- or overinvestment in human capital in the presence of income taxes. The higher is the exogenously given labor tax rate $\bar{t}>0$, the larger is the fiscal externality due to the implicit tax $\frac{\pi_{e}}{1-\pi_{e}}$ on human capital. If education is riskincreasing, $\pi_{e}>0$, education should be subsidized more in order to internalize the fiscal externality. If education has a risk-mitigating effect, $\pi_{e}<0$, there is an implicit subsidy on human capital which is ceteris paribus off-set by an explicit tax on education.

By combining these two arguments, it becomes apparent that optimal education subsidies are unambiguously positive when education and labor supply are complementary $\left(\varepsilon_{l s}>0\right)$ and there is underinvestment in education $\left(\pi_{e}>0\right)$. In that case, education subsidies help to reduce both tax distortions in labor supply and to internalize the fiscal externality of underinvestment in education. If, on the other hand, education hedges against labor market risks $\left(\pi_{e}<0\right)$ the two arguments pull in opposite directions as long as education and labor remain complementary $\left(\varepsilon_{l s}>0\right)$. Therefore, the sign of the education subsidy cannot be unambiguously determined. In particular, education should be taxed if $\frac{\varepsilon_{l s}}{\varepsilon_{e s}}<-\pi_{e}$. In that case, socially undesirable overinvestment in education is relatively large compared to the complementarity of education with labor supply.

These findings are related to the 'Siamese twins' intuition in Bovenberg and Jacobs (2005). In particular, education policies are optimally employed to off-set the distortions arising from social insurance. Provided that optimal education subsidies are non-negative $\left(\frac{\varepsilon_{l s}}{\varepsilon_{e s}}+\pi_{e}>0\right)$, more aggressive social insurance (larger $\left.t\right)$ requires higher education subsidies (and vice versa). However, the intuition for our findings is different than Bovenberg and Jacobs (2005) for two reasons. First, education subsidies do not generate inequality since everyone is identical ex ante. ${ }^{15}$ Consequently, education should be subsidized on a net basis if education and labor are complementary (ceteris paribus). In Bovenberg and Jacobs (2005) education is not subsidized on a net basis, because subsidizing education of ex ante differing individuals generates more inequality due to the ability bias in education. Jacobs and Bovenberg (2008) show that both effects (lower tax wedge on labor and more inequality) cancel out exactly, and education subsidies are optimally zero (on a net

\footnotetext{
${ }^{15}$ This is also the reason why education subsidies are not used for insurance.
} 
basis) with their assumptions on the earnings function. Second, there are two distortions on human capital investment in the current model. The tax system distorts labor supply and missing insurance markets distort human capital investment. The latter mechanism is absent in Bovenberg and Jacobs (2005). This paper shows that this provides a novel channel in which either education subsidies or education taxes may be used to internalize the fiscal externalities arising from over- or underinvestment in human capital.

Proposition 2. Education subsidies do not provide income insurance and are only used for efficiency reasons in order to offset the distortions of income taxes on labor supply and educational investment. First, education subsidies help to off-set the tax-induced distortions of social insurance on labor supply when education and work effort are complementary. Education subsidies are higher if labor and education are more complementary. Second, education subsidies (taxes) are used to internalize the fiscal externality resulting from socially undesirable underinvestment (overinvestment) in human capital in the absence of insurance markets. Optimal education subsidies are higher (lower) if there is more under-(over-)investment in human capital.

\subsection{Optimal Tax Cum Education Policy}

By combining the expressions for the optimal tax and education policies (46) and (48) from Appendices A.3 and A.4 we obtain the optimal tax rate $\hat{t}$ and education subsidies $\hat{s}$ if the government simultaneously optimizes income taxes and education subsidies:

$$
\begin{gathered}
\frac{\hat{t}}{1-\hat{t}}=\frac{\xi}{\varepsilon_{l t}-\frac{\varepsilon_{l s}}{\varepsilon_{e s}} \varepsilon_{e t}}, \\
\frac{\hat{s}}{1-\hat{s}}=\left(\frac{\frac{\varepsilon_{l s}}{\varepsilon_{e s}}}{1-\pi_{e}}+\frac{\pi_{e}}{1-\pi_{e}}\right) \hat{t} .
\end{gathered}
$$

Note that all statements in section 4.3 about the optimal education subsidy for given tax policy carry over to the case in which optimal tax and education policies are simultaneously derived. For this reason we do not discuss this expression further and refer to the previous section. We therefore bolster Anderberg's (2008) findings that the risk properties of human capital are crucial for the design of optimal human capital policies. While Anderberg (2008) considers a general set of information-rich non-linear policy instruments, our analysis shows that the risk properties of human capital are also key for optimal human capital policies under linear policy instruments, which are less informationally demanding. Optimal education policies will not ensure aggregate efficiency in human capital investment, since not all income risk will be fully diversified. Moreover, our analysis points out that the fiscal externalities associated with missing insurance markets are crucial for the design of educational policy. 
The optimal tax rate $\hat{t}$ is no longer directly affected by the risk-wedge, since, compared to equation (25), the risk premium in education $\pi_{e}$ ceases to enter the optimal tax formula. Hence, the income tax no longer exacerbates underinvestment if $\pi_{e}>0$ and no longer mitigates overinvestment if $\pi_{e}<0$. The expression for the optimal income tax indeed confirms that the education subsidy perfectly internalizes the fiscal externality arising from under- or overinvestment in human capital. Education subsidies are a more efficient instrument to internalize the fiscal externality than income taxes, since the latter also distort labor supply. This finding mirrors the results on optimal taxation in the presence of externalities by Sandmo (1975, pp. 92, 95). He shows that externalities should optimally be internalized by only correcting the price of the commodity which causes the externality in an additive way ('additive property'). In our case this 'commodity' is education. We also find that the correction term enters additively in the optimal tax expression.

The interpretation of the optimal tax rate therefore changes slightly, since it is now exclusively used for insurance purposes. Naturally, the optimal tax rate still increases in the marginal benefits of insurance $(\xi)$ and decreases in higher tax-induced distortions in labor supply $\left(\varepsilon_{l t}\right)$. The new optimal tax expression (28), however, reveals that the optimal income tax increases if education and labor supply become more complementary as indicated by $\frac{\varepsilon_{l s}}{\varepsilon_{e s}}$. See also the expression for the optimal education subsidy. Education subsidies boost labor supply if $\varepsilon_{l s}>0$ and thereby help to off-set the tax distortions on labor effort. Consequently, income taxes increase (ceteris paribus). If education responds very elastically to education subsidies, $\varepsilon_{e s}$ is large, optimal tax rates are lower, since subsidies are more distortionary and exacerbate overinvestment in education. If there is no income risk or if the government is not concerned about risk, $\xi=0$, there is no income taxation, implying that education subsidies are also zero $(\hat{t}=\hat{s}=0)$, because in that case there are neither tax distortions nor fiscal externalities.

The optimal use of education policy does not unambiguously increase optimal income tax rates (for given $\xi$ ) as can be inferred from comparing the optimal tax policy cum education subsidies, in equation (28), with the optimal tax rate in equation (25), where education policy is absent $(s=0)$. Intuitively, one would expect the optimal tax rate to be higher if the government has more instruments. This conclusion is not necessarily valid in the current second-best setting with multiple distortions. Indeed, the intuition is only confirmed for the case where $\pi_{e}>0$. Without education subsidies, income taxation exacerbates the non-tax distortions from missing insurance markets, which causes a negative fiscal externality. A lower tax rate is thus optimal. With optimal education policy internalizing the fiscal externality, the optimal income tax is unambiguously higher (even if $\left.\varepsilon_{l s}=0\right)$. However, in the case of overinvestment in human capital due to missing insurance markets $\left(\pi_{e}<0\right)$, the income tax features a positive fiscal externality by mitigating distortions in human capital investment. When education subsidies, or even education 
taxes (e.g., if $\varepsilon_{l s}=0$ ), are available, there is, however, no longer a role for the income tax to correct for overinvestment in human capital. As a result optimal income taxes may well be lower. The following proposition summarizes our findings.

Proposition 3. If labor and education are more complementary, both the optimal tax rate and optimal education subsidies increase. If the risk premium on education rises, there is a rise in optimal education subsidies as well. If labor supply and education are complementary and there is underinvestment in education due to missing insurance markets, education policy allows for more social insurance compared to tax policy alone. If education hedges against labor market risk, optimal tax rates with education policy could be lower than without education policy if the complementarity between education and labor is sufficiently weak.

Our findings are importantly related to Hamilton (1987), Anderberg and Andersson (2003) and Anderberg (2008). Hamilton (1987) extends Eaton and Rosen (1980b) and analyzes capital taxes as an indirect education subsidy. Hamilton (1987) is right in pointing out that there remains underinvestment in education when income taxes are optimally set. Consequently, a capital tax could be welfare enhancing, because a capital tax is an indirect education subsidy. Since we assume that education is verifiable, we can allow for direct education subsidies. We have shown that the role for education policy is to internalize the fiscal externality associated with underinvestment. Therefore, we are able to show that the use of education subsidies is always welfare enhancing. Hamilton (1987) needs strong assumptions (constant absolute risk aversion and inelastic labor supply) to show that his education policy is desirable, since capital taxes also distort savings in contrast to education subsidies. ${ }^{16}$

Anderberg and Andersson's (2003) analysis is closest to ours, the major difference being that these authors assume that the government can impose a mandatory level of education centrally. Consequently, there is no fiscal externality in human capital investment - which explains the absence of the risk premium in their optimal tax formula (in equation 11). Education policy then has an insurance effect, because it replaces selfinsurance of households in a decentralized setting. Anderberg and Andersson (2003, p. 1523) state that "The insight is thus that if education moderates wage uncertainty, a second-best policy should, rather unambiguously, encourage the formation of human capital (relative to the first-best), while if education exacerbates wage uncertainty the overall conclusion is ambiguous." Though this statement is correct, it would be misleading to conclude that education subsidies (or taxes) would be an optimal policy when education decisions are made at the decentralized level. Indeed, if households choose educational

\footnotetext{
${ }^{16}$ In the absence of risk, Jacobs and Bovenberg (2005) show that capital needs to be taxed if educational investment cannot be verified, even when labor supply is endogenous and much weaker restrictions are imposed on the utility function.
} 
investment themselves, there is no insurance effect of educational policy. More importantly, the novel finding of our paper is that in the presence of income taxation, there will be socially 'excessive' overinvestment (underinvestment) by households, compared to the constrained second-best optimal amount of overinvestment (underinvestment). This, ceteris paribus, calls for a policy that discourages (encourages) educational investment. Even under linear policy instruments it can be misleading to obtain policy recommendations from looking at the optimal wedges on individual choices and comparing these with the first-best choice-rules. The policy implementation in our setting is the polar opposite of what the wedges on education seem to suggest. As has also been stressed by Golosov et al. (2003, 2006), there is generally no clear-cut correspondence between tax wedges and tax rates that would implement optimal second-best allocations. We believe that this could also be an important issue in the recent papers in the new dynamic public finance tradition (see, e.g., da Costa and Maestri, 2007, and Anderberg, 2008). In light of this discussion, we rephrase our results in the following corollary.

Corollary 1. From a positive (negative) tax wedge on education compared to the firstbest level cannot be concluded that education should be subsidized (taxed) if human capital investment is made at the decentralized level and the government only has indirect control over individual choices via subsidies and taxes.

\section{Conclusions}

This paper analyzed optimal social insurance and education policy. The optimal income tax strikes a balance between benefits of social insurance and the distortions in labor supply. The optimal income tax is higher if education and work are more complementary, since the government can indirectly off-set labor-tax distortions by subsidizing education. Optimal education subsidies unambiguously increase if education and labor are more complementary. In that case, subsidies on education are a more attractive instrument to fight tax distortions on labor supply. The optimal income tax is not determined by the risk properties of human capital, but optimal education policies are. Education subsidies are not used to off-set under- or overinvestment in human capital in the absence of taxation, because this would upset the optimal private response to market risks. However, the non-insurable risk due to missing insurance markets gives rise to a fiscal externality from income taxation. Boosting education yields more (less) tax revenues if there is underinvestment (overinvestment) in human capital. Subsidizing (taxing) education is optimal in order to internalize the fiscal externality originating from the missing insurance markets, ceteris paribus. If education is a risky activity there is a strong role for subsidizing education on a net basis to off-set the distortions of social insurance on human capital investments. Social insurance will then increase. However, if education 
hedges against labor market risk, the case for education subsidies is weakened, and social insurance may even be reduced compared to the outcome in the absence of education subsidies.

Whether education subsidies or education taxes should be employed is an empirical question that can only be answered by knowing the risk-properties of human capital. In reality, both risk-reducing and risk-increasing education types appear to be present, see also the discussion in section 2. For example, lawyers may be subject to less income risk than construction workers. Optimal education policies should generally differentiate between education types and need to be tailored to the risk-properties of each type of education. Future research could extend the current model to a two-period setting in order to analyze linear capital taxes, besides education subsidies. Further, the model could be used to analyze time-consistent education policies as in Pereira (2008).

\section{A Appendix}

\section{A.1 Second-order Conditions in Household Optimization}

$U$ denotes expected utility of individuals:

$$
U(e, l)=\mathcal{E}[u((1-t)[\Phi(\theta, l, e)-(1-s) e]+T)]-v(l)
$$

The first-order conditions for the optimal choices of education and labor are given by

$$
\begin{gathered}
U_{e}=(1-t) \mathcal{E}\left[u^{\prime}\left(\Phi_{e}-(1-s)\right)\right]=0, \\
U_{l}=(1-t) \mathcal{E}\left[u^{\prime} \Phi_{l}\right]-v^{\prime}=0 .
\end{gathered}
$$

First-order conditions are necessary, but not sufficient. The Hessian matrix $H$ of the second-order partial derivatives can be written as

$$
H \equiv\left[\begin{array}{cc}
\mathcal{E}\left[u^{\prime} \Phi_{e e}+u^{\prime \prime}(1-t)\left(\Phi_{e}-(1-s)\right)^{2}\right] & \mathcal{E}\left[u^{\prime} \Phi_{e l}+u^{\prime \prime}(1-t) \Phi_{l}\left(\Phi_{e}-(1-s)\right)\right] \\
\mathcal{E}\left[u^{\prime} \Phi_{e l}+u^{\prime \prime}(1-t) \Phi_{l}\left(\Phi_{e}-(1-s)\right)\right] & \mathcal{E}\left[u^{\prime} \Phi_{l l}+u^{\prime \prime}(1-t) \Phi_{l}^{2}\right]-\frac{v^{\prime \prime}}{(1-t)}
\end{array}\right]
$$

For utility to reach a maximum the Hessian matrix should be negative definite. Hence, the leading principal minors should switch signs. The first leading principal minor is always negative $\left(U_{e e}<0\right)$, due to diminishing returns to education $\left(\Phi_{e e}<0\right)$ and concavity of the utility function $\left(u^{\prime \prime}<0\right)$. The second leading principal minor must therefore be positive. Hence, the second-order conditions are summarized by $U_{e e} U_{l l}-U_{e l}^{2}>0$. Upon 
substitution of the second derivatives, we can state the second-order condition as

$$
\begin{aligned}
& \mathcal{E}\left[u^{\prime} \Phi_{e l}+u^{\prime \prime}(1-t) \Phi_{l}\left(\Phi_{e}-(1-s)\right)\right]^{2} \\
< & \mathcal{E}\left[u^{\prime} \Phi_{e e}+u^{\prime \prime}(1-t)\left(\Phi_{e}-(1-s)\right)^{2}\right]\left(\mathcal{E}\left[u^{\prime} \Phi_{l l}+u^{\prime \prime}(1-t) \Phi_{l}^{2}\right]-v^{\prime \prime} /(1-t)\right) .
\end{aligned}
$$

Rewriting yields the expression in the text.

\section{A.2 Deriving Slutsky Equations under Risk}

In order to derive the expected utility compensated substitution effects, we calculate how much lump-sum income $\omega$ an individual should receive (pay) in order to keep its expected utility constant when either the tax rate or the subsidy rate changes. This is equivalent to deriving the expenditure function and applying Shephard's lemma. First, totally differentiate the expected utility function at constant utility to obtain

$$
d U=\mathcal{E}\left[u^{\prime} d c\right]-v^{\prime} d l=0
$$

Totally differentiating the budget constraint (while allowing for lump-sum income $\omega$ ) gives

$$
d c=-(\Phi-(1-s) e) d t+(1-t)\left(\Phi_{e}-(1-s)\right) d e+(1-t) e d s+(1-t) \Phi_{l} d l+d \omega
$$

Substitution of the last expression into the differentiated utility function, and using the first-order conditions for utility maximization, yields

$$
-\mathcal{E}\left[u^{\prime}(\Phi-(1-s) e)\right] d t+\mathcal{E}\left[u^{\prime}\right](1-t) e d s+\mathcal{E}\left[u^{\prime}\right] d \omega=0
$$

After applying Steiner's Rule, and using the definition of the insurance characteristic $\xi$ in equation (24), the following compensations for tax and subsidy changes are obtained

$$
\begin{gathered}
\left.\frac{d \omega}{d t}\right|_{d s=0}=\frac{\partial \omega}{\partial t}=(1-\xi) \mathcal{E}[\Phi]-(1-s) e, \\
\left.\frac{d \omega}{d s}\right|_{d t=0}=\frac{\partial \omega}{\partial s}=-(1-t) e
\end{gathered}
$$


The Slutsky equations are, therefore, given by

$$
\begin{aligned}
& \frac{\partial e}{\partial t}=\frac{\partial e^{*}}{\partial t}-\frac{\partial \omega}{\partial t} \frac{\partial e}{\partial T}=\frac{\partial e^{*}}{\partial t}-((1-\xi) \mathcal{E}[\Phi]-(1-s) e) \frac{\partial e}{\partial T} \\
& \frac{\partial l}{\partial t}=\frac{\partial l^{*}}{\partial t}-\frac{\partial \omega}{\partial t} \frac{\partial l}{\partial T}=\frac{\partial l^{*}}{\partial t}-((1-\xi) \mathcal{E}[\Phi]-(1-s) e) \frac{\partial l}{\partial T} \\
& \frac{\partial e}{\partial s}=\frac{\partial e^{*}}{\partial s}-\frac{\partial \omega}{\partial s} \frac{\partial e}{\partial T}=\frac{\partial e^{*}}{\partial s}+(1-t) e \frac{\partial e}{\partial T} \\
& \frac{\partial l}{\partial s}=\frac{\partial l^{*}}{\partial s}-\frac{\partial \omega}{\partial s} \frac{\partial l}{\partial T}=\frac{\partial l^{*}}{\partial s}+(1-t) e \frac{\partial l}{\partial T}
\end{aligned}
$$

where the asterisk $\left(^{*}\right)$ denotes compensated demand and supply functions.

\section{A.3 Optimal Taxation}

We simplify the first-order condition for the tax rate $t$ (equation (21)) by substituting Roy's lemma and the Slutsky equations (40) and (41) from Appendix A.2:

$$
\begin{aligned}
& \frac{\mathcal{E}\left[-u^{\prime}(.)(\Phi(.)-(1-s) e)\right]}{\eta}+\mathcal{E}[\Phi(.)-(1-s) e] \\
+ & \mathcal{E}\left[\Delta_{e}\right]\left(\frac{\partial e^{*}}{\partial t}-[(1-\xi) \mathcal{E}[\Phi(.)]-(1-s) e] \frac{\partial e}{\partial T}\right) \\
+ & \mathcal{E}\left[\Delta_{l}\right]\left(\frac{\partial l^{*}}{\partial t}-[(1-\xi) \mathcal{E}[\Phi(.)]-(1-s) e] \frac{\partial l}{\partial T}\right)=0 .
\end{aligned}
$$

After using Steiner's Rule, the definition of $\xi$ from equation (24), and substitution of the first-order condition for $T$ from equation (23) we find

$$
\xi \mathcal{E}[\Phi(.)]=-\mathcal{E}\left[\Delta_{e}\right] \frac{\partial e^{*}}{\partial t}-\mathcal{E}\left[\Delta_{l}\right] \frac{\partial l^{*}}{\partial t}
$$

Substitute $\Delta_{e}$ and $\Delta_{l}$ from equations (19) and (18), as well as $\mathcal{E}\left[\Phi_{e}\right]=\frac{1-s}{1-\pi_{e}}$ from equation (12), and rearrange to obtain

$$
\xi=\frac{t}{1-t} \varepsilon_{l t}+\left(\frac{\pi_{e}(s+t(1-s))-s}{(1-s)(1-t)}\right) \varepsilon_{e t}
$$

where $\varepsilon_{e t} \equiv-\frac{\mathcal{E}\left[\Phi_{e}(.)\right] e}{\mathcal{E}[\Phi(.)]} \frac{\partial e^{*}}{\partial t} \frac{1-t}{e}$, and $\varepsilon_{l t} \equiv-\frac{\mathcal{E}\left[\Phi_{l}(.)\right] l}{\mathcal{E}[\Phi(.)]} \frac{\partial l^{*}}{\partial t} \frac{1-t}{l}$ are the negatively income weighted expected utility compensated elasticities of education and labor with respect to the tax rate. The elasticities are weighted by the expected shares of education and labor in total earnings. Finally, applying $\bar{s}=0$, rearranging and collecting terms results in the expression in the text. 


\section{A.4 Optimal Education Policy}

We simplify the first-order condition for education by substituting Roy's lemma and the Slutsky equations (42) and (43) from Appendix A.2:

$$
\mathcal{E}\left[(1-t) e\left(\frac{u^{\prime}}{\eta}+\Delta_{l} \frac{\partial l}{\partial T}+\Delta_{e} \frac{\partial e}{\partial T}-1\right)\right]+\mathcal{E}\left[\Delta_{e}\right] \frac{\partial e^{*}}{\partial s}+\mathcal{E}\left[\Delta_{l}\right] \frac{\partial l^{*}}{\partial s}=0
$$

Since $e$ is not stochastic, we have $\mathcal{E}\left[(1-t) e\left(\frac{u^{\prime}}{\eta}+\Delta_{l} \frac{\partial l}{\partial T}+\Delta_{e} \frac{\partial e}{\partial T}-1\right)\right]=0$ from the first-order condition for $T$ in (23). Hence,

$$
\frac{\mathcal{E}\left[\Delta_{e}\right] e}{1-s} \frac{\partial e^{*}}{\partial s} \frac{1-s}{e}+\frac{\mathcal{E}\left[\Delta_{l}\right] l}{1-s} \frac{\partial l^{*}}{\partial s} \frac{1-s}{l}=0
$$

Substituting $\Delta_{e}$ and $\Delta_{l}$ from equations (19) and (18) as well as using the first-order condition for learning $\mathcal{E}\left[\Phi_{e}\right]=\frac{1-s}{1-\pi_{e}}$ from equation (12) results in

$$
\bar{t} \varepsilon_{l s}+\frac{\pi_{e}(s+\bar{t}(1-s))-s}{(1-s)} \varepsilon_{e s}=0
$$

where we defined the subsidy elasticities analogously to tax elasticities as the income weighted expected utility compensated elasticities: $\varepsilon_{e s} \equiv \frac{\mathcal{E}\left[\Phi_{e}(.)\right] e}{\mathcal{E}[\Phi(.)]} \frac{\partial e^{*}}{\partial s} \frac{1-s}{e}$ and $\varepsilon_{l s} \equiv \frac{\mathcal{E}\left[\Phi_{l}(.)\right] e}{\mathcal{E}[\Phi(.)]} \frac{\partial l^{*}}{\partial s} \frac{1-s}{l}$. Rewriting yields the expression in the text.

\section{References}

Anderberg, D., 2008. Optimal Policy and the Risk-Properties of Human Capital Reconsidered. CESifo Working Paper No. 2451, Munich.

Anderberg, D., and F. Andersson, 2003. Investments in Human Capital, Wage Uncertainty, and Public Policy. Journal of Public Economics 87, 1521-1537.

Atkinson, A.B., and J.E. Stiglitz, 1980. Lectures on Public Economics. New York: McGraw-Hill.

Belzil, C., and J. Hansen, 2004. Earnings Dispersion, Risk Aversion and Education. Research in Labor Economics 23, 335-358.

Bovenberg, A.L., and Jacobs, B. 2003. Redistribution and Education Subsidies are Siamese Twins. Tinbergen Institute Discussion Paper 05-037/3.

Bovenberg, A.L., and Jacobs, B. 2005. Redistribution and Education Subsidies are Siamese Twins. Journal of Public Economics 89, 2005-2035. 
Cremer, H., and F. Gahvari, 1995a. Uncertainty and Optimal Taxation: In Defense of Commodity Taxes. Journal of Public Economics 56, 291-310.

Cremer, H., and F. Gahvari, 1995b. Uncertainty, Optimal Taxation and the Direct Versus Indirect Tax Controversy. Economic Journal 105, 1165-1179.

Da Costa, C.E., and Maestri, L.J., 2007. The Risk Properties of Human Capital and the Design of Government Policies. European Economic Review 51, 695-713.

Diamond, P.A., and J.A. Mirrlees, 1978. A Model of Social Insurance with Variable Retirement. Journal of Public Economics 10, 295-336.

Diamond, P.A., and J.A. Mirrlees, 1986. Payroll-Tax Financed Social Insurance with Variable Retirement. Scandinavian Journal of Economics 88, 25-50.

Eaton, J., and H.S. Rosen, 1980a. Labor Supply, Uncertainty, and Efficient Taxation. Journal of Public Economics 14, 365-374.

Eaton, J., and H.S. Rosen, 1980b. Taxation, Human Capital, and Uncertainty. American Economic Review 70, 705-715.

Feldstein, M. S., 1972. Distributional Equity and the Optimal Structure of Public Prices. American Economic Review 62, 32-36.

Golosov, M., N. Kocherlakota, and A. Tsyvinski, 2003. Optimal Indirect and Capital Taxation. Review of Economic Studies 70, 569-587.

Golosov, M., A. Tsyvinski, and I. Werning, 2006. New Dynamic Public Finance: A User's Guide. NBER Macroeconomic Annual, 317-363.

Gould, E.D., O. Moav, and B.A. Weinberg, 2000. Precautionary Demand for Education, Inequality, and Technological Progress. Journal of Economic Growth 6, 285-316.

Grochulski, B., and T. Piskorski, 2006. Risky Human Capital and Deferred Capital Income Taxation. Federal Reserve Bank of Richmond Working Paper No. 06-13.

Hamilton, J., 1987. Optimal Wage and Income Taxation with Wage Uncertainty. International Economic Review 28, 373-388.

Hartog, J., 2005. Schooling as a Risky Investment. Proceedings of the Royal Dutch Academy of Sciences 68.

Heller, W.P., and D.A. Starrett, 1976. On the Nature of Externalities. In: Lin, S.A.Y. (ed.). Theory and Measurement of Externalities. Academic Press, New York. 
Jacobs, B., 2005. Optimal Income Taxation with Endogenous Human Capital. Journal of Public Economic Theory 7, 295-315.

Jacobs, B., and A.L. Bovenberg, 2005. Human Capital and Optimal Positive Taxation of Capital Income. CEPR Working Paper No. 5047, London.

Jacobs, B., and A.L. Bovenberg, 2008. Optimal Taxation of Human Capital and the Earnings Function. CESifo Working Paper No. 2250, Munich.

Kaplow, L., 1994. Taxation and Risk-taking: A General Equilibrium Perspective. National Tax Journal 47, 789-798.

Levhari, D., and Y. Weiss, 1974. The Effect of Risk on the Investment in Human Capital. American Economic Review 64, 950-963.

Palacios-Huerta, I., 2004. An Empirical Analysis of the Risk Properties of Human Capital Returns. American Economic Review 93, 948-964.

Palacios-Huerta, I., 2006. Risk and Market Frictions as Determinants of the Human Capital Premium. Brown University, mimeo.

Pereira, J., 2008. Commitment and Redistribution Policy with Endogenous Skills, European University Institute, mimeo.

Sandmo, A., 1975. Optimal Taxation in the Presence of Externalities. Swedish Journal of Economics 77, 86-98.

Schindler, D., and H. Yang, 2007. Risky Human Capital Formation Requires 'Siamese Twins'. Research Group Heterogenous Labor Discussion Paper 07/10, University of Konstanz, Konstanz.

Sinn, H.-W., 1996. Social Insurance, Incentives, and Risk-taking. International Tax and Public Finance 3, 259-280.

Wigger, B.U., and R. von Weizsäcker, 2001. Risk, Resources, and Education - Public versus Private Financing of Higher Education. IMF Staff Papers 48, 547-560.

Varian, H.R., 1980. Redistributive Taxation as Social Insurance. Journal of Public Economics 14, 49-68. 


\section{CESifo Working Paper Series}

for full list see www.cesifo-group.org/wp

(address: Poschingerstr. 5, 81679 Munich, Germany, office@cesifo.de)

2465 Claudia M. Buch, The Great Risk Shift? Income Volatility in an International Perspective, November 2008

2466 Walter H. Fisher and Ben J. Heijdra, Growth and the Ageing Joneses, November 2008

2467 Louis Eeckhoudt, Harris Schlesinger and Ilia Tsetlin, Apportioning of Risks via Stochastic Dominance, November 2008

2468 Elin Halvorsen and Thor O. Thoresen, Parents' Desire to Make Equal Inter Vivos Transfers, November 2008

2469 Anna Montén and Marcel Thum, Ageing Municipalities, Gerontocracy and Fiscal Competition, November 2008

2470 Volker Meier and Matthias Wrede, Reducing the Excess Burden of Subsidizing the Stork: Joint Taxation, Individual Taxation, and Family Splitting, November 2008

2471 Gunther Schnabl and Christina Ziegler, Exchange Rate Regime and Wage Determination in Central and Eastern Europe, November 2008

2472 Kjell Erik Lommerud and Odd Rune Straume, Employment Protection versus Flexicurity: On Technology Adoption in Unionised Firms, November 2008

2473 Lukas Menkhoff, High-Frequency Analysis of Foreign Exchange Interventions: What do we learn?, November 2008

2474 Steven Poelhekke and Frederick van der Ploeg, Growth, Foreign Direct Investment and Urban Concentrations: Unbundling Spatial Lags, November 2008

2475 Helge Berger and Volker Nitsch, Gotcha! A Profile of Smuggling in International Trade, November 2008

2476 Robert Dur and Joeri Sol, Social Interaction, Co-Worker Altruism, and Incentives, November 2008

2477 Gaëtan Nicodème, Corporate Income Tax and Economic Distortions, November 2008

2478 Martin Jacob, Rainer Niemann and Martin Weiss, The Rich Demystified - A Reply to Bach, Corneo, and Steiner (2008), November 2008

2479 Scott Alan Carson, Demographic, Residential, and Socioeconomic Effects on the Distribution of $19^{\text {th }}$ Century African-American Stature, November 2008

2480 Burkhard Heer and Andreas Irmen, Population, Pensions, and Endogenous Economic Growth, November 2008 
2481 Thomas Aronsson and Erkki Koskela, Optimal Redistributive Taxation and Provision of Public Input Goods in an Economy with Outsourcing and Unemployment, December 2008

2482 Stanley L. Winer, George Tridimas and Walter Hettich, Social Welfare and Coercion in Public Finance, December 2008

2483 Bruno S. Frey and Benno Torgler, Politicians: Be Killed or Survive, December 2008

2484 Thiess Buettner, Nadine Riedel and Marco Runkel, Strategic Consolidation under Formula Apportionment, December 2008

2485 Irani Arraiz, David M. Drukker, Harry H. Kelejian and Ingmar R. Prucha, A Spatial Cliff-Ord-type Model with Heteroskedastic Innovations: Small and Large Sample Results, December 2008

2486 Oliver Falck, Michael Fritsch and Stephan Heblich, The Apple doesn't Fall far from the Tree: Location of Start-Ups Relative to Incumbents, December 2008

2487 Cary Deck and Harris Schlesinger, Exploring Higher-Order Risk Effects, December 2008

2488 Michael Kaganovich and Volker Meier, Social Security Systems, Human Capital, and Growth in a Small Open Economy, December 2008

2489 Mikael Elinder, Henrik Jordahl and Panu Poutvaara, Selfish and Prospective: Theory and Evidence of Pocketbook Voting, December 2008

2490 Maarten Bosker and Harry Garretsen, Economic Geography and Economic Development in Sub-Saharan Africa, December 2008

2491 Urs Fischbacher and Simon Gächter, Social Preferences, Beliefs, and the Dynamics of Free Riding in Public Good Experiments, December 2008

2492 Michael Hoel, Bush Meets Hotelling: Effects of Improved Renewable Energy Technology on Greenhouse Gas Emissions, December 2008

2493 Christian Bruns and Oliver Himmler, It's the Media, Stupid - How Media Activity Shapes Public Spending, December 2008

2494 Andreas Knabe and Ronnie Schöb, Minimum Wages and their Alternatives: A Critical Assessment, December 2008

2495 Sascha O. Becker, Peter H. Egger, Maximilian von Ehrlich and Robert Fenge, Going NUTS: The Effect of EU Structural Funds on Regional Performance, December 2008

2496 Robert Dur, Gift Exchange in the Workplace: Money or Attention?, December 2008

2497 Scott Alan Carson, Nineteenth Century Black and White US Statures: The Primary Sources of Vitamin D and their Relationship with Height, December 2008 
2498 Thomas Crossley and Mario Jametti, Pension Benefit Insurance and Pension Plan Portfolio Choice, December 2008

2499 Sebastian Hauptmeier, Ferdinand Mittermaier and Johannes Rincke, Fiscal Competition over Taxes and Public Inputs: Theory and Evidence, December 2008

2500 Dirk Niepelt, Debt Maturity without Commitment, December 2008

2501 Andrew Clark, Andreas Knabe and Steffen Rätzel, Boon or Bane? Others' Unemployment, Well-being and Job Insecurity, December 2008

2502 Lukas Menkhoff, Rafael R. Rebitzky and Michael Schröder, Heterogeneity in Exchange Rate Expectations: Evidence on the Chartist-Fundamentalist Approach, December 2008

2503 Salvador Barrios, Harry Huizinga, Luc Laeven and Gaëtan Nicodème, International Taxation and Multinational Firm Location Decisions, December 2008

2504 Andreas Irmen, Cross-Country Income Differences and Technology Diffusion in a Competitive World, December 2008

2505 Wenan Fei, Claude Fluet and Harris Schlesinger, Uncertain Bequest Needs and LongTerm Insurance Contracts, December 2008

2506 Wido Geis, Silke Uebelmesser and Martin Werding, How do Migrants Choose their Destination Country? An Analysis of Institutional Determinants, December 2008

2507 Hiroyuki Kasahara and Katsumi Shimotsu, Sequential Estimation of Structural Models with a Fixed Point Constraint, December 2008

2508 Barbara Hofmann, Work Incentives? Ex Post Effects of Unemployment Insurance Sanctions - Evidence from West Germany, December 2008

2509 Louis Hotte and Stanley L. Winer, The Demands for Environmental Regulation and for Trade in the Presence of Private Mitigation, December 2008

2510 Konstantinos Angelopoulos, Jim Malley and Apostolis Philippopoulos, Welfare Implications of Public Education Spending Rules, December 2008

2511 Robert Orlowski and Regina T. Riphahn, The East German Wage Structure after Transition, December 2008

2512 Michel Beine, Frédéric Docquier and Maurice Schiff, International Migration, Transfers of Norms and Home Country Fertility, December 2008

2513 Dirk Schindler and Benjamin Weigert, Educational and Wage Risk: Social Insurance vs. Quality of Education, December 2008

2514 Bernd Hayo and Stefan Voigt, The Relevance of Judicial Procedure for Economic Growth, December 2008 
2515 Bruno S. Frey and Susanne Neckermann, Awards in Economics - Towards a New Field of Inquiry, January 2009

2516 Gregory Gilpin and Michael Kaganovich, The Quantity and Quality of Teachers: A Dynamic Trade-off, January 2009

2517 Sascha O. Becker, Peter H. Egger and Valeria Merlo, How Low Business Tax Rates Attract Multinational Headquarters: Municipality-Level Evidence from Germany, January 2009

2518 Geir H. Bjønnes, Steinar Holden, Dagfinn Rime and Haakon O.Aa. Solheim, ,Large' vs. ,Small' Players: A Closer Look at the Dynamics of Speculative Attacks, January 2009

2519 Jesus Crespo Cuaresma, Gernot Doppelhofer and Martin Feldkircher, The Determinants of Economic Growth in European Regions, January 2009

2520 Salvador Valdés-Prieto, The 2008 Chilean Reform to First-Pillar Pensions, January 2009

2521 Geir B. Asheim and Tapan Mitra, Sustainability and Discounted Utilitarianism in Models of Economic Growth, January 2009

2522 Etienne Farvaque and Gaël Lagadec, Electoral Control when Policies are for Sale, January 2009

2523 Nicholas Barr and Peter Diamond, Reforming Pensions, January 2009

2524 Eric A. Hanushek and Ludger Woessmann, Do Better Schools Lead to More Growth? Cognitive Skills, Economic Outcomes, and Causation, January 2009

2525 Richard Arnott and Eren Inci, The Stability of Downtown Parking and Traffic Congestion, January 2009

2526 John Whalley, Jun Yu and Shunming Zhang, Trade Retaliation in a Monetary-Trade Model, January 2009

2527 Mathias Hoffmann and Thomas Nitschka, Securitization of Mortgage Debt, Asset Prices and International Risk Sharing, January 2009

2528 Steven Brakman and Harry Garretsen, Trade and Geography: Paul Krugman and the 2008 Nobel Prize in Economics, January 2009

2529 Bas Jacobs, Dirk Schindler and Hongyan Yang, Optimal Taxation of Risky Human Capital, January 2009 